\title{
Új, orosz nyelvú szerkezeti-morfológiai földgömb a Virtuális Glóbuszok Múzeumában, és ami mögötte áll
}

\author{
Márton Mátyás
}

DOI: $10.30921 / G K \cdot 72.2020 .3 .1$

Absztrakt: Alig több mint 30 esztendeje annak, hogy 1989 augusztusában a Nemzetközi Térképészeti Társulás budapesti konferenciáján a Kartográfiai Vállalatnál készült $40 \mathrm{~cm}$ átmérôjû́, szétszedhetô szerkezeti-morfológiai földgömb angol nyelvú változata elnyerte a legjobb szemléltetöeszköznek járó díjat (Anson-Gutsell 1989, Papp-Váry 1990, Rátóti 1990). Ez a siker két oktatási intézmény [a Kossuth Lajos Tudományegyetem (ma Debreceni Egyetem) és az Eötvös Loránd Tudományegyetem], valamint két magyar vállalat (a Kartográfiai Vállalat és a Tanszergyártó és Értékesítő Vállalat) együttmúködése eredményeképpen született. A páratlan kiadvány máig az egyetlen, hazánkban szerkesztett és kiadott tematikus földgömb, amelyet viszonylag nagy példányszámban sokszorosítottak is. Ma már alig találkozhatunk vele, még az Országos Széchényi Könyvtár Térképtára sem ôriz ilyet, mivel a készítô és/vagy a forgalmazó sajnálatosan nem tett eleget az érvényes kötelespéldány-rendeletnek. Egyebek mellett ezért is került sor feldolgozásukra korábban a Virtuális Glóbuszok Múzeumában (VGM). (http://terkeptar.elte.hu/vgm).

A jelen tanulmányban a szerzó áttekinti e glóbuszok történetét: az 1986-ban elkészült magyar (VGM ID 8, 9, 10) és az 1988-ban megjelent angol nyelvú változatokat (VGM ID 66, 67, 68). Bemutatja születésük közvetlen tudományos elözményeit és - mivel taneszközról van szó - a kiadás hosszadalmas eljárási folyamatát. Ismerteti a címben jelzett orosz nyelvü változatnak az Eötvös Loránd Tudományegyetem Térképtudományi és Geoinformatikai Tanszékén most folyó munkálatait is, amelyek eredményeképpen tovább bövülhet a Virtuális Glóbuszok Múzeumának földgömbállománya, és rámutat az új feldolgozás szoros kapcsolatára a korábbi két kiadással.

Abstract: It has been just for more than thirty years that the in English-language version of the detachable structuralmorphological globe of the Earth with $40 \mathrm{~cm}$ diameter produced by the Cartographia Enterprise won the prize of the best demonstration aid (Anson-Gutsell 1989, Papp-Váry 1990, Rátóti 1990) at the Budapest conference of the International Cartographic Association in August 1989. This success was the result of the cooperation between two education institutions (Kossuth Lajos University and Eötvös Loránd University) and two Hungarian firms (Cartographia Enterprise and School Equipment Producing and Marketing Company). This unique product has been the only thematic earth globe designed and published in Hungary and which was duplicated in a relatively number. It is a rarity today, even the Map Collection of the National Széchényi Library has no copy of it. This is one of the reasons why this globe has been placed in the Virtual Globes Museum (VGM) (http://terkeptar.elte.hu/vgm).

This paper gives an overview of the history of these globes: the Hungarian versions made in 1986 (VGM ID 8, 9, 10) and the English versions published in 1988 (VGM ID 66, 67, 68). It introduces the immediate scientific antecedents of their birth and - being a demonstration aid - the circumstantial process of publishing. The paper also presents the ongoing work with the Russian version of the globe carried out at the Department of Cartography and Geoinformatics, Eötvös Loránd University. This will lead to the expansion of the number of globes in the VGM. The close relationship between the new product and the former two editions is also pointed out.

Kulcsszavak: térképtörténet, technológiatörténet, földgömbök, Virtuális Glóbuszok Múzeuma Keywords: map history, history of technology, earth globes, Virtual Globes Museum

\section{Az elốzmények}

1984-ben a Kartográfiai Vállalatnál született egy díjazott MÉM-OFTH ${ }^{1}$ tanulmány, ami egyben a 820013 munkaszámú, „A tengerfenék-domborzat ábrázolásának vizsgálata” címet viselő kutatási munka beszámolója is volt a Kartográfiai Vállalatnál (KV) (MártonKôvári 1984a és 1984b). Ennek térképmellékletei - a két A3-as méretú, a 40 cm-es földgömb vetületében készült

\footnotetext{
1 MÉM: Mezôgazdasági és Élelmezésügyi Minisztérium; OFTH: Országos Földügyi és Térképészeti Hivatal
}

négy gömbszegmens mintafeldolgozása - összevetve a 40 cm-es ún. tanári domborzati földgömb tengeri mélységábrázolásával, meggyőzô érvként szolgált ez utóbbi elavult voltának bemutatására (1. ábra). E feldolgozás fontos szerepe miatt kandidátusi dolgozatomban (Márton 1991) rögzítettem a kulcsszereplőket is. (Ezek szerint: „A tengerfenék-domborzatábrázolásának vizsgálata címú kutatási téma... Készült a Kartográfiai Vállalat 2. Szerkesztô osztályán, 1984-ben. Szerkesztette: Márton Mátyás. Tervezte: Kóvári József. Summer: Bárkainé Neményi
Márta. Rajz, litográfia: Bakos János, Gyenes Gyula).” A rajz itt természetesen a tisztázatirajz-készítést jelenti. Meg kell még említeni, hogy a nyomtatást a vállalat Sokszorosító osztálya végezte.

Abban az idôben még nem nagyon használtak számítógépet a térképkészítésben, a vetületi transzformáció igen munka- és idôigényes volt, így nem igen törekedtek a kiadók a térképi tartalom egyik vetületbôl a másikba történô átszerkesztésére. Sokkal inkább arra fordítottak idôt, hogy a célméretaránynál nagyobb 

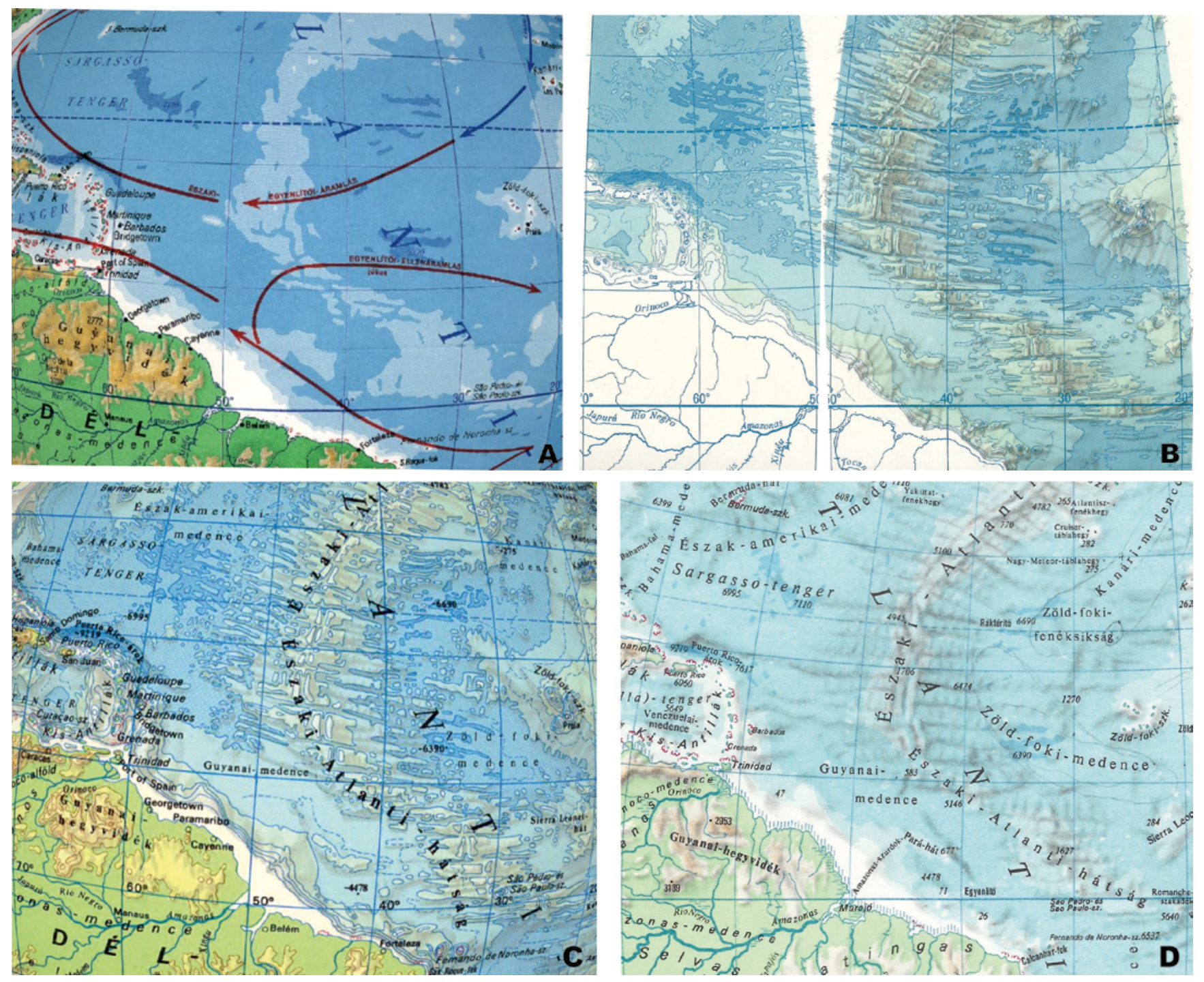

1. ábra. Az Atlanti-óceán ugyanazon területe

A) a 40 cm-es tanári domborzati földgömbön (1981) (VGM ID 84), B) a mintafeldolgozáson (1984),

C) a 25 cm-es gömbön (VGM ID 41) és D) az 1985-ben megjelent Nagy Világatlaszban

méretarányú, de lehetôleg ugyanolyan vagy nagyon közelálló vetületû legyen a forrástérkép. A tengeri tematikák - így a mélységrajz forrása is - általában Mercator-vetületû́ térkép volt (a hajózás szögtartó vetületû́ térképigényének megfelelóen), nemigen lehetett elkerülni tehát a vetületi transzformációt. Ily módon hiába is készült az elvégzett kutatás eredményeinek felhasználására vonatkozó érvelés - gazdasági számításokkal is megpróbálva alátámasztani azt - nem sok esély mutatkozott a munka folytatására, gyors befejezésére.

A sors azonban kiszámíthatatlan. 1985 nyarán - mint a korábbi években is - az Eötvös Loránd Tudományegyetem (ELTE) Térképtudományi Tanszékének hallgatói érkeztek a 4 . tanévük végén szakmai gyakorlatra a KV-hoz, a 2. Szerkesztố osztályra. Osztályvezetôm, Ajtay Ágnes [1934-1994] térképész nem először, és talán nem is véletlenül - engem bízott meg a gyakorlat vezetésével, sôt a feladat meghatározását is rám bízta. Ố már évek óta tanított a tanszéken külsô óraadóként, és az elsố díjas OFTH-pályázat után szorgalmazta is, hogy készítsem el egyetemi doktori értekezésemet, ami ekkor már folyamatban volt (Márton 1985a). Ennek kapcsán támogatta azt is, hogy szükség szerint elmehessek a Térképtudományi vagy a Geofizikai Tanszékre. Így a kapcsolatom az ELTEtanszékekkel ebben az idôben (is) élố volt. (1974-ben szereztem geofizikus, 1975-ben kartográfus oklevelet.)

A nyári gyakorlatos hallgatók munkájának eredményeképpen az egész
Föld óceáni és tengeri területeire elkészült a GEBCO, a General Bathymetric Chart of the Oceans (Az óceánok általános mélységtérképe) (Márton 2002) felhasználásával a tengerfenék-domborzat 10 milliós egyenlítôi méretarányú elôterve, amely az idézett tanulmány alapján az ábrázolásra kiválasztott mélységvonalakat tartalmazta. Ráadásul olyan módon, hogy Jesús Reyes Núñes (ma tanszéki kollégám), további két hetet, így az egész júliust az osztályunkon töltve ellenőrizte hallgatótársai munkáját, és kiegészítette, javította is azt.

A sors különös játéka eredményezte, hogy ez a munka még tovább folytatódhatott. A Kartográfiai Vállalat Külkereskedelmi osztálya megrendelte egy $25 \mathrm{~cm}$-es földgömb domborzati terveinek elkészítését 
a 2. Szerkesztô osztálynál². Igény mutatkozott külföldön a $25 \mathrm{~cm}$ átmérôjû́ politikai földgömbön túl egy ugyanilyen méretû domborzati gömbre is. 1985-ben egyébként a vállalat a $25 \mathrm{~cm}$-es politikai glóbuszait a hazai piacra szánt magyar mellett angol, német és cseh nyelven, majd 1987-tôl lengyel nyelven is gyártotta. Hasonlóan a $16 \mathrm{~cm}$-es gömbnek a magyar mellett angol, német, lengyel és cseh nyelvú kiadásai is voltak (Márton 1988). A vállalat 1990-ig összesen mintegy 600 ezer (!) földgömböt gyártott, és ebból 100 ezer (!) darab exportra, idegen nyelven készült (Kovács-Márton 1989).

A megrendelés úgy szólt, hogy a négy (magyar, angol, német és cseh) nyelvi mutációban ${ }^{3}$ készítendô 25 cm-es domborzati glóbusz tartalmát az $40 \mathrm{~cm}$ átmérôjứ tanári földgömbbôl kell levezetni. A múszaki terv - az árkalkuláció - is ennek megfelelôen „visszafogott” volt ${ }^{4}$. Ebben az idôben irányító térképszerkesztố voltam, és a földgömbök hozzám tartoztak a 2. Szerkesztô osztályon. Több kört is futottam azért, hogy ne az elavult $40 \mathrm{~cm}$-es gömb tartalma kerüljön az új $25 \mathrm{~cm}$-esre. Végül csak

\footnotetext{
${ }^{2}$ Ebben az idôben már önálló elszámolású egységekként múködtek az egyes részlegek a vállalaton belül. A tudományos kutatás eredményeinek alkalmazása a térképszer kesztésben - szemben a múszaki fejlesztéssel - a nagyobb idốráfordítás miatt gyakran "ráfizetéses" volt.

3 "Mutációk: Ugyanazon térképi tartalommal készülô földgömbök, kézi térképek atlaszok (de más kiadványok) különbözó nyelvú változatai. Az elnevezés onnan eredhet, hogy ezeket színpárhuzamban nyomva igen gazdaságos az egy példányra vetített költség, mert pl. csak a fekete szín tartalma tér el - mutálódik. Az ilyen nyomtatás feltétele, hogy a „mutáns” rész - rendszerint a névrajz - egy színben legyen. Ezért került át a korábbi idôszakhoz viszonyítva a térképek víznév-anyaga a sötétkékbôl a feketébe. A nyomtatáskor ilyen esetben kinyomtatják a kívánt példányszámot pl. a magyar névanyaggal, a gép megállt, csak az angol névanyagot tartalmazó lemezt kell a magyar helyére beemelni, a többi lemez marad, és folytatódhat a nyomás, amíg elóáll a szükséges számú angol nyelvű példány. Hasonlóan történhet további nyelvekkel is a nyomtatás folytatása.

4 Úgy tûnhetett, hogy ha a $16 \mathrm{~cm}$-es gömbök iránt van érdeklódés, ,jó lesz az a tartalom a $25 \mathrm{~cm}$-es gömb vásárlóinak is". Ugyanilyen kereskedô-hozzáállás miatt soha nem került magyar piacra ugyanezen földgömb magyar mutációja, „hiszen az a $25 \mathrm{~cm}$-es politikai glóbusz konkurense lenne, és összesen úgy sem lehetne több példányt eladni a magyar piacon $25 \mathrm{~cm}$-es gömbökből”.
}

Ajtay Ágnes nem kis áldozatvállalása (az osztály biztos anyagi veszteségének tudatában) mentette meg a „tudományt", aki vállalta a felmerülố többletköltségeket. Így születhetett meg a mind a szárazföldi, mind a tengeri domborzat ábrázolása szempontjából legmodernebb magyar földgömb a Kartográfiai Vállalatnál, amely az akkor kiadás eloott álló, teljesen új szerkesztésû́ Nagy világatlasz (1985) hasonló méretarányú óceáni térképlapjai tartalmi részletességét is meszsze meghaladja a mélységábrázolás szempontjából (1. ábra). A hitelesség megkívánja, hogy kimondjuk: a summer alkalmazása sokat segített a világatlasz egyébként igen elnagyolt mélységiréteg-színezésén (0, -200, $-2000,-4000,-6000,-8000$ m-es értékhatárok alkalmazása)! A 25 cm-es glóbusz szerkesztési-tervezési munkái a 2. Szerkesztố osztályon folytak, miután az új „Szerkesztői eloóirást” elkészítettem (Márton 1985b). Ezt Kovács Pál' , a KV felelôs térképszerkesztôje ellenőrizte és hagyta jóvá. A litográfiai feldolgozás összeállításában - mint korábban, a kutatási mintaszelvények készítésénél is - Chabada Gyula, irányító kartolitográfus volt segítségemre. A szerkesztői előírásban szerepel, hogy az ELTE negyedéves hallgatói által elkészített tengerfenék-domborzati előtervek felhasználása során „Helyesbíteni kell az egyetemisták által elkövezett hibákat! Ennek érdekében a $25 \mathrm{~cm} ø$ gömbre való betervezés során nézni kell az eredeti GEBCO-szelvények mélységvonalrajzát is."

Az új, párhuzamosan négy nyelvi mutációban készülố $25 \mathrm{~cm}$-es domborzati földgömb nyomtatásban is megjelenó - 5000, 3000, 1500,

5 1957-ben az ELTE-n dip-
lomát szerzett térképész.
1000, 500, 200, 0, (mélyföld), -200, $-1000,-2000,-3000,-4000,-5000$, $-6000,-7000$ m-es - izovonalait a tengeri területeken szükség szerint a két szomszédos érték közötti felezô és negyedelô mélységvonalak egészítik ki. Természetesen magassági- és mélységiréteg-színezés és egységes - szárazföldi és tengeri (!) - summer segíti a szemléletes domborzati kép kialakítását. További eltérés a korábbi gyakorlattól, egy visszafogott, a kék mélységiréteg-színezést alig megtörô zöldes árnyalat bevitele (két fokozatban, törtsárga szín 10 és 20\%-os „hozzáadásával") a 2-3000 és a 3-4000 m közötti óceáni és tengeri területekre, amely a hátságvidék és a kontinentális lejtô alsóbb szintjeinek jó kiemelését eredményezi. Így az óceánok nagy szerkezeti egységeinek (a kontinensperemi, a mélytengeri és a hátsági területeknek) kitûnô elkülönítésére nyílik lehetôség. Az alkalmazott színek száma nyolc: sötétkék, világoskék, törtsárga (világossárga), szürke, fekete, vörös, barna és zöld (2. ábra).

Kandidátusi dolgozatomban itt is rögzítettem a kulcsszereplóket. Ezek szerint: „A $25 \mathrm{~cm}$ átmérójú

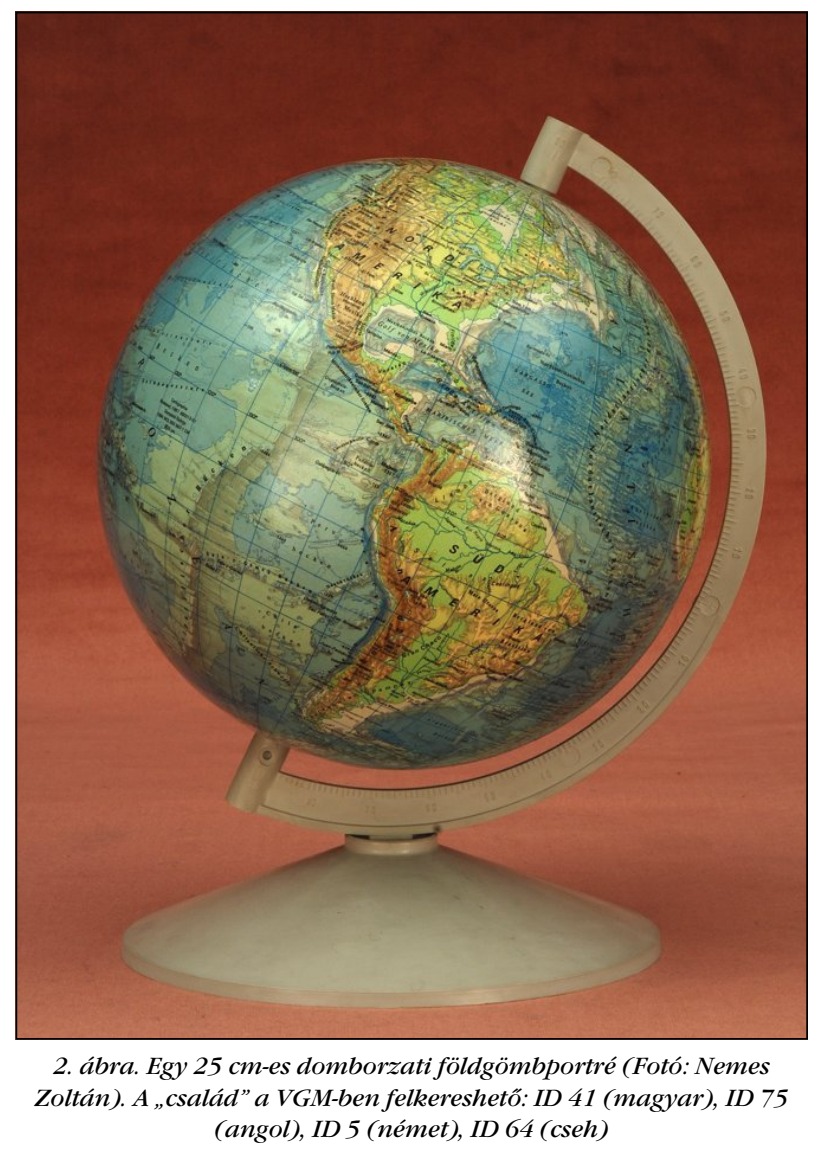


domborzati földgömb ... Készült a Kartográfiai Vállalat 2. Szerkesztô és Kartolitográfiai osztályán, 19851986-ban. Szerkesztette: Márton Mátyás. Tervezte: Kôvári József (domborzatrajz), Mészáros Piroska (névrajz). Summer: Tóvizi Kálmánné6. Rajz, litográfia: Nagy László).” A rajz itt is a tisztázatirajz-készítést jelenti. Kiegészítésül pedig meg kell jegyezni, hogy a nyomtatást a vállalat Sokszorosító osztálya, a kasírozást pedig a Földgömbcsoport vagy a Texgráf végezte.

\section{Egy szemléltetóeszköz gyártástörténete az 1980-as évek közepén}

1984-ben dr. Hajdu Lajos [1941-2010], a Kossuth Lajos Tudományegyetem Gyakorló Általános Iskolájának szakvezetô tanára újítási javaslatot nyújtott be a Tanszergyártó és Értékesítô Vállalathoz (TANÉRT). A „Szétszedhető Föld-modell” nevet viselố taneszköz a glóbusz felületén a forgalomban levố $40 \mathrm{~cm}$ átmérôjû́ tanári földgömb tengerábrázolását átvéve a szárazföldi területeken a középiskolai Földrajzi atlasz szerkezeti-morfológiai tematikus tartalmát adja, amely az egész földfelszínre kiegészül a litoszféralemez-határok bemutatásával.

Az 1984. október 10-én Kovács Pál felelős szerkesztő által készített és Dudar Tibor [1931- ${ }^{8}$ fószerkesztô által ellenốrzött árajánlat arra utal, hogy a TANÉRT hamar felkereste a Kartográfiai Vállalatot (KV) a glóbusz térképnyomatai elkészítésének ügyében, és kellô tájékoztatást is adhatott, hiszen a „múszaki terven” a földgömb alapadatain túl a következô szöveg is szerepel: „A megrendelô által átadott anyagot $40 \mathrm{~cm} \varnothing$ földgömbre át kell

\footnotetext{
${ }^{6}$ A Szovjetunióban a Moszkvai Geodéziai, Légifényképezési és Kartográfiai Egyetemen 1967-ben kartográfus diplomát szerzett.

7 Ebben az idôben a KV más kiadványaiban (térképek, atlaszok) a szerkesztô bizottság tagjain túl már feltüntették a munkában résztvevôket (a munkára fordított összes idố mennyiségének függvényében). A földgömbökön azonban a hely hiányában csak a vállalat megnevezése, a kiadás helye és éve valamint a munkaszám szerepelt.

8 1957-ben az ELTE-n diplomát szerzett térképész.
}

dolgozni. A mintán lévő tematikus anyag a tudomány mai állása szerint, különösen a lemezekre és a mélységvonalakra vonatkozóan elavult. Ezeket saját erôból teljesen átdolgoznánk és a többi tematikus anyagot is megfelelô lektorral ill. lektorokkal ellenôriztetni kell." (A múszaki terv készítôi ismerték az ekkor már kinyomtatott tengerdomborzati mintaszelvényeket, és mint geofizikus végzettségú kollégával, aki a munka irányításának várományosa is volt, konzultáltak velem.)

A TANÉRT ezt követôen végigjárta az új taneszköz bevezetésének szokásos lépcsófokait. Az 1985. április 16-án, a TANÉRT-nél tartott ülésen elvégezték „A Föld szerkezetét bemutató - szétszedhetô - földgömb szakbizottsági vizsgálatá"-t, amelyen a vállalat szakérốin túl az Országos Pedagógiai Intézet képviseletében Varajti Károly, valamint a szerzôn (az újítón), dr. Hajdu Lajoson túl „külsô” szakértőként dr. Horváth Ferenc [1944-2018] tudományos munkatárs (ELTE) és Hubai József gimnáziumi tanár vett részt. A megbeszélés során elhangzott észrevételek és a felmerült kérdések megvitatása után az a döntés született, hogy „A szakbizottság az eszköz TB-re való vitelét a javítások elvégzése után ajánlja."

A Tanszerbizottság (TB) 1985. június 4-én tartott ülésének 2. pontjaként tárgyalta a „Szétszedhető Földmodell (újítás) tanári demonstrációs eszköz a középiskolai és az általános iskolai földrajz (fakultáció) tanításához (TANÉRT elooterjesztés)" címú témát. Az itt született határozat kimondja: »A Taneszköz Bizottság a „Szétszedhetô Föld-modell” megnevezésû eszköz iskolai beszerzésének és használatának engedélyezését a közzététel elótt álló taneszközjegyzék fontossági besorolása szerint javasolja engedélyezésre. Amennyiben az eszköz nem szerepel az új eszközjegyzékben, akkor II-es fontossági besorolást javasol."

1985. október 23-án került sor „a Szerkezeti Föld-modell krúdájának ${ }^{9}$

\footnotetext{
9 Krúda: a nyomdagépbôl kikerült hajtogatatlan kézitérképnyomat vagy atlaszív. Esetünkben a szegmensekre fel nem vágott földgömbtérkép és a metszetek nyomata.)
}

megrendelésével kapcsolatos szakmai megbeszélés"-re. Ezen dr. Hajdu Lajos (tanár, újító), a $\mathrm{KV}$ részérôl Dudar Tibor (fôszerkesztô), Kovács Pál (felelôs térképszerkesztô) és Márton Mátyás (irányító térképszerkesztô), míg a TANÉRT képviseletében Jackovics József (a 2. sz. Gyáregység fốmérnöke), Berta Imre osztályvezetố és Molnárné Sárváry Mónika (csoportvezetô) vettek részt. A szétszedhetô hordozógömb múszakitechnikai követelményeinek tisztázását követôen „Szakmai, pedagógiai szempontból az alábbi megállapodás jött létre:

- A külsố gömbkrúdára a névrajzot az újító dr. Hajdu Lajos kibóvíti és elkészíti magyar, angol és orosz nyelven és a Kartográfiának megküldi.

- A tengerfenék ábrázolása a Kartográfia új krúdája szerint készül a legmodernebb térképszerkesztési elveknek megfelelôen." (Ez utóbbi pont Márton Mátyás javaslatára született és érveit a 820013 munkaszámú, „A tengerfenékdomborzat ábrázolásának vizsgálata" címet viselô kutatási munka két A3-as méretû mintaszelvényének bemutatásával támasztotta alá, összehasonlítva azzal a $40 \mathrm{~cm}$-es tanári földgömb sematikus tengerábrázolását.)

A rendelkezésre álló dokumentumok szerint dr. Hajdu Lajos 1985. november 25-én küldte meg Dudar Tibornak a kért anyagot „Kiegészítés a Szerkezeti földgömb leírásához" címú 12 oldalas összeállításában. Ezt követôen került sor az angol névanyag szakmai lektorálására, amelyet Meskó Attila [1940-2008] az ELTE Geofizikai Tanszékének vezetô professzora (valószínúleg Horvát Ferenc bevonásával) végzett. Az orosz nyelvú anyagot Bassa Lászlóné (KV 2. Szerkesztô osztály) 1986. március 20-án vitte „szakmai és nyelvi lektorálásra” moszkvai tanulmányútjára dr. Hajdu Lajos március 6-án kelt hozzájárulásával és Domokos György igazgató március 10-i engedélyével.

A Kartográfiai Vállalatnál 1986. április 8-án tartott szúk szakmai egyeztetésen, dr. Hajdu Lajos, Kovács Pál és Márton Mátyás vett részt. Márton 
javaslatára a megbeszélésen fontos, a glóbusz tartalmát jelentôsen befolyásoló, tovább módosító döntések születtek az „Emlékeztető” szerint:

1.) Dr. Hajdu Lajos elküldi a KV részére a gömb használatához készülő magyarázó szöveges kiadvány egy kézirati példányát, várhatóan április végére.

2.) Tekintettel arra, hogy - valószínúleg gyártási okok miatt - a TANÉRT 2. sz. Gyáregysége a gömb feldarabolását módosította (amelyrôl csak a KV-t értesítette, az újítót nem) a metszetek szükségessé váló átszerkesztését a KV elvégzi. Ennek megfelelôen a lemeztektonikai jelenleg $90^{\circ}$-nyi egyenlítôi metszet $180^{\circ}$-os területet fed majd le, a K-i hosszúság $10^{\circ}$-ától a Ny-i hosszúság $170^{\circ}$-áig terjedôen. Így nagyobb hangsúlyt kap az aktív és a passzív kontinensperem ábrázolása. A metszet tematika tartalmát úgy kell megszerkeszteni, hogy a gömb felszínén megjelenó tartalomhoz szervesen kapcsolódjék. Át kell helyezni ennek következtében a Föld belsejében uralkodó fizikai jellemzôk (hullámterjedési sebesség, nyomás, sûrúség) ábraanyagát az új lemeztektonikai metszettel átellenes oldalra. az északi félgömb „talpára”. Megállapodtunk abban is, hogy a jelkulcsot (helyesebben: jelmagyarázatot $[M M]$ ) valamelyik - tematikát nem tartalmazó - gömbi metszet felületén helyezzük el.

3.) Az 1985. október 23-án lefolytatott tárgyalásnak megfelelốen a tengerfenék-domborzat ábrázolásához a KV új módszerét használjuk fel. Az egész Földre egységesebb képi megjelenés érdekében a KV javasolja a szárazföldi területeken is olyan szintvonalrajz és summer alkalmazását (visszafogott szürke háttértérképként), amely a tematikus tartalmat nem zavarja. Amennyiben a próbanyomat elkészülése után ez a megoldás zavarónak tûnik, lehetôség van ennek elhagyására.

4.) Az orosz mutációs névanyag Szovjetunióbeli lektorálása során fölvetődött az a kérdés, hogy a Föld belsố szerkezetét ábrázoló különbözô korú földmodellek (pl.: Suess ${ }^{10}, 1895$;

\footnotetext{
${ }^{10}$ Eduard Suess [1831-1914] osztrák geológus és paleontológus.
}

Goldschmidt $^{11}, 1922$ stb.) között miért nem szerepel szovjet modell, ahogyan a magyar Egyed László [1914-1970] modellje pl. helyet kapott. Várható tehát esetleges külföldi megrendelés esetén olyan igény, hogy ezt a részt a (próba) nyomat elkészítése után át kell dolgozni.

5.) Megállapodtunk abban, hogy mivel a középiskolai Földrajzi atlasz 1984-es kiadásában a kontinensek szerkezeti-morfológiai felépítését bemutató térképek kis mértékben eltérnek az újító által a KV-nek átadott Föld-modelltôl, a KV az atlaszban szereplô tematikának megfelelốen átalakítja a tematikát, de az atlasztól eltérôen a gömb eredeti jelkulcsának megfelelốen bontva ábrázolja az ókori (helyesen: óidei [MM]) röghegységeket (Kaledonidák, Variszcidák), illetve a fiatal Pacifikusés Eurázsiai-hegységrendszereket.

6.) Dr. Hajdu Lajos hozzájárul ahhoz, hogy a tematikus tartalomban (pl. a lemezhatárok futásában) jelentkezô kisebb pontatlanságokat a KV javítsa.

A fentiek figyelembevételével készült el a 630237 munkaszámú „múszaki terv”, amely külön tartalmazza, hogy „A szedés és a fotó másoló munkák kivételével mindent a 2. Szerkesztô o. készít, a szerelést is. A sokszorosítást a Sokszorosító osztály készíti!"

1986. április 28-án dr. Hajdu Lajos a 18 oldalas tanszerismertetô kéziratot Márton Mátyásnak megküldte.

Egy - Ajtay Ágnes (a 2. Szerkesztô osztály vezetôje) által a Kartolitográfiai osztálynak 1986. május 12-én küldött - FELJEGYZÉS rávilágít a fentebb idézett „múszaki terv"-ben megfogalmazottak értelmére: „A most elkészült $25 \mathrm{~cm}$ átmérôjû́ domborzati földgömb sötétkék (partvonal, vízrajz, fokhálózat, mélységvonalrajz) és barna (szintvonalak) anyagát kérjük összemásolni. A másolatról 1,63-szoros nagyítást kérünk pozitív, lemezhez álló filmre. Msz.: 630 237." Ez azt jelenti, hogy a Föld-modell térképnyomatainak előállításához a $25 \mathrm{~cm}$-es domborzati gömb tisztázati rajzi munkarészeinek

\footnotetext{
${ }^{11}$ Victor Moritz Goldschmidt [1888-1947] svájci születésú geokémikus.
}

1,63-szoros nagyítású anyagát kívántuk felhasználni. Ekkor már a szerkesztő-tervezô munka teljes erôbedobással folyt.

A TANÉRT 1986. IX. 22. dátummal szállított 3 db szétszedhetố hordozógömb-mintát a KV-nak. Ezt követôen készített a KV a már májusban elkészült 25 cm-es földgömb 163\%-os nagyítású összemásolt vonalas anyagából különbözố hossztorzítású rajzolatú és különbözó fajta papírokra nyomatokat a próbakasírozáshoz a TANÉRT számára. Ezek közül a megfelelố nyúlást mutató változatot október 31-ére határozták meg, és november 3-án kelt levelében tájékoztatta erról Domokos Györgyöt, a KV igazgatóját Jackovics József, a TANÉRT gyáregységi főmérnöke: „Megállapítottuk, hogy a 605 jelzésû anyag hálómérete tökéletes, míg a levelünkhöz mellékelt papíranyag viselkedett a ragasztás során a legjobban.” A KV érkeztetés november 5-én történt, de a fố- és a felelôs szerkesztônek kiszignált iratot ôk csak 11-én látták. (Sokáig gondolkodtam, hogy mi történhetett? Hiszen a határidô mindenkit sürgetett ekkor már! Kortörténeti adalék: november 7-ét ünnepeltük. Péntekre esett abban az évben.) 1986. november 12-én rendelte meg Ajtay Ágnes a Sokszorosító osztályon „a 630237 munkaszámú Szerkezeti földgömb tisztázati, és lemezhez álló raszterezett anyagának előállítását”. A próbanyomatokat december 1-jén kaptam kézhez, és 2-án kézbesítố vitte a TANÉRT-nek. Gyôri János gyáregységigazgató december 11-i levelében tájékoztatta a KV fôszerkesztôjét, hogy „A mellékelten visszaküldött próbanyomat a kolofonon történt változtatással gyártható.” És elindulhattak a nyomdagépek...

A kasírozás, lakkozás, csomagolás, forgalmazás feladata már a TANÉRT-re várt.

\section{A 40 cm-es szétszedhetó Föld-modell magyar változata}

Az elốzóekben megismerhettük azt az eljárásrendet, amin egy külsố megrendelốáltal kezdeményezett munkának „át kellett esnie”, amíg megvalósult. 
Itt röviden áttekintem, hogyan folyt az érdemi kartográfiai munka ennél a glóbusznál, amely sok kihívással szembesítette készítôit.

Hosszas egyeztetés és együttgondolkodás eredményeképpen született meg maga a hordozógömb is. Az eredeti elképzelés két egymásra helyezhetố félgömbrôl szólt, amelynek egyik részébôl kiemelhetố gömbhéjak szemléltették volna a földszerkezetet. Számos, egymásba jól illeszthetố elemet kellett volna így elôállítani, amelyek igen sérülékenynyé tették volna ezt a taneszközt. A végsố megoldás gyártása technológiai szempontból roppant egyszerú. Mindössze egyfajta elemet: egynegyed gömböt kell elôállítani, és páronként egymáshoz képest 90 fokkal elforgatva összeragasztani. Két ilyen sajátos alakú „félgömböt” összeillesztve áll elő a hordozógömb (3. ábra). A gömb külsố felületére kasírozhatjuk (ragaszthatjuk) fel a földgömbtérkép szegmenseit (esetünkben a fél és teljes gömbkétszögeket), míg a belsố felületek alkalmasak a Föld belsô szerkezetével kapcsolatos ábrák, fizikai jellemzók metszeteken történô bemutatására.

Természetesen mindennek ára van. Az egyszerû hordozógömb gyártása kissé megnehezíti a kartográfiai szerkesztômunkát, de még inkább a kasírozást! A földgömbtérkép-nyomatokon a $6 \mathrm{db}$ sarktól sarkig nyúló, valamint a $2 \times 6$ darab kettévágott, az Egyenlítôtôl az Északi- illetve a Délisarkig nyúló gömbszegmenst $2 \times 2$ $\mathrm{db} 10^{\circ}$ pólustávolságú $90^{\circ}$-os, illetve $270^{\circ}$-os körcikkre vágott pólussapka egészíti ki. A kasírozás ennél a gömbnél igényli a legnagyobb odafigyelést, különös gondosságot. Az általános megoldással szemben (14 darab: 12 gömbkétszög +2 pólussapka) itt 30 (!) db felületelem $(6$ teljes $+6 \times 2$ fél gömbkétszög $+2 \times 2$ pólussapkadarab + 8 metszet) tökéletes illeszkedését kell elérni a kasírozás során. A szétszedhetô földgömbrészek belsố felületén elhelyezkedô különbözô tematikus tartalmú gömbmetszetek szerkesztése és kasírozása sem könnyíti meg a munkát.

A glóbuszfelületet borító földgömbtérkép a szárazföldeken szerkezeti-morfológiai tematikát, az óceáni és tengeri területeken pedig a $25 \mathrm{~cm}$-es természetföldrajzi földgömbnek megfelelố tengerfenékdomborzati ábrázolást tartalmaz (mélységiréteg-színezés). A domborzat érzékeltetését a szárazföldön a tematikus tartalmat nem zavaró, igen visszafogott szürke szintvonalrajz, a tengereken sötétkék mélységvonalrajz, a teljes földfelszínen egységes (szárazföldi és tengeri) szürke summer segíti. A glóbusz az egész Földön egységes jelkulccsal mutatja a litoszféralemezek határait; megkülönböztetve a közeledô, a távolodó és az egymás mellett elcsúszó lemezszegélyeket. A finom rajzolatú mélységábrázolás jól támogatja a lemeztektonikai tematikus tartalmat, felhívja a figyelmet a szerkezet és a morfológia kapcsolatára (pl. az óceáni hátságok központi hasadékvölgyének létrejötte a távolodó lemezszegélyeken, a törésövek az egymás mellett elcsúszó lemezszegélyek mentén vagy az árkok kialakulása az egymáshoz közeledó litoszféralemezek határainál stb.)

A gömb szétszedett állapotában válnak láthatóvá a Föld belsố szerkezetére vonatkozó információkat tartalmazó metszetek. Az elsô: a Föld belsố felépítésére kialakított elméleteket szemlélteti Suess 1896os modelljétôl Egyed 1955-ös asztrofizikai földmodelljéig. A második metszet a földrengéshullámok terjedési sebessége, a nyomás és a sưrûség változásának alakulását mutatja be a felszíntől a Föld középpontjáig. A harmadik: a hômérséklet, a vegyi összetétel változását, a különbözô - szeizmológiai kutatásokkal kimutatott - határfelületeket, valamint a lemeztektonika elméletéhez kapcsolódó belsố szerkezetet (litoszféra, asztenoszféra, mezoszféra stb.) a felszíntôl a földközéppontig mérethelyes ábrázolásban adja. A negyedik szemlélteti a gömb - mint geometriai idom - középponti szögei és a földrajzi szélességi körök helye között fennálló összefüggést. Az ötödik metszet ismét a lemeztektonikai modellt mutatja be (az Egyenlítő síkjában, a mezoszféráig mélységi torzítással) oly módon, hogy a metszeten ábrázolt jelenségek egyértelmúen hozzárendelhetôk a földgömbborító térkép, a „földfelszín” domborzati anyagához. Jól érzékelhetô itt
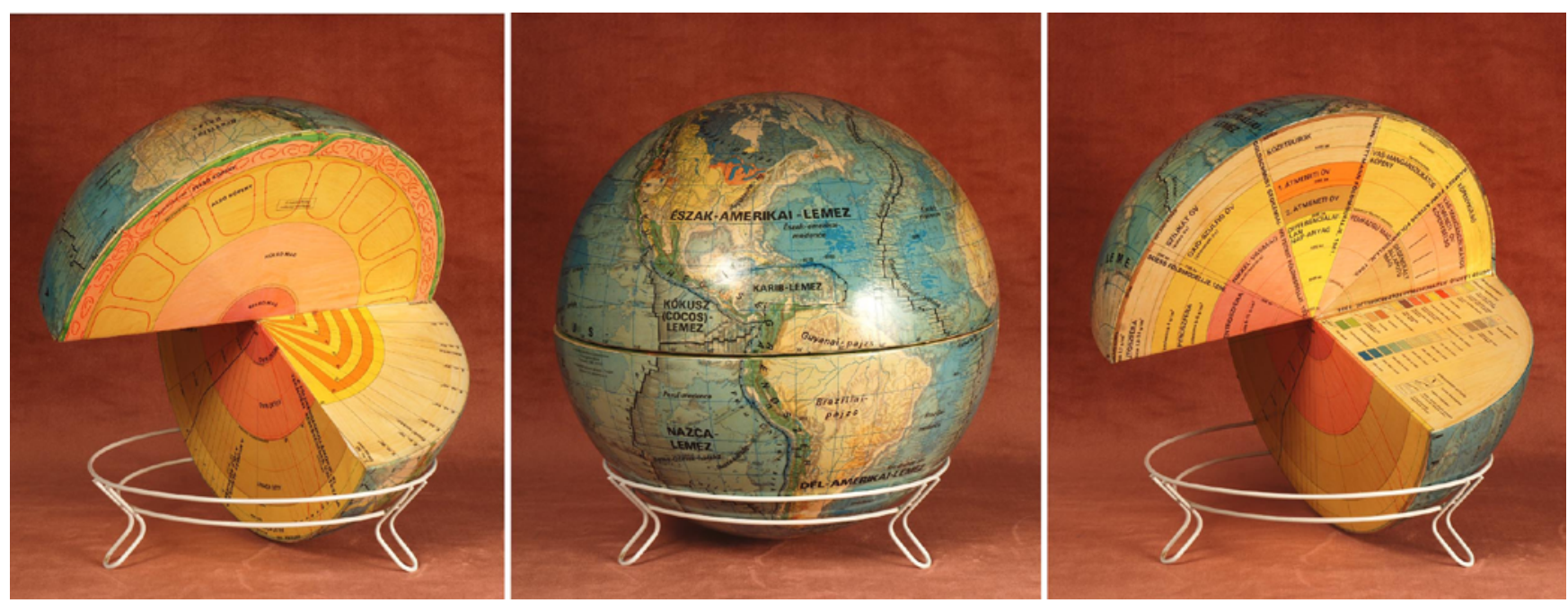

3. ábra A glóbusz magyar nyelvü változata összerakva és szétszedve (Fotók: Nemes Zoltán).

Ugyanez a VGM-ben felkeresve: ID 9, ID 10, ID 8 
a kontinensek alatti kéregvastagodás, a kontinens alá betolódó óceáni lemez és a mélytengeri árok, valamint a kontinensen jelentkezô vulkanizmus kapcsolata stb. A hatodik metszeten kapott helyet a jelmagyarázat. A további metszetek a tanult anyag visszakérdezését szolgálják (felirat nélküli, az elôzôkkel egyező ábrázolások).

A földgömbtérkép nyomási színeinek száma nyolc: fekete, sötétkék, világoskék, barna, törtsárga, sárga, vörös és szürke. Fekete: a teljes névrajz, kolofon, lemezhatárok, árkos süllyedékek. Sötétkék: fokhálózat, partvonal, vízrajz, a jégfelszínek domborzata (Grönland, Antarktika) gleccserrajz, vízfelület (tavak), mélységvonalrajz, batimetria. Világoskék: batimetria, szerkezeti morfológia. Barna: hegyrajzi jelek, szerkezeti morfológia. (Tört)sárga: batimetria (kontinentális lejtő, hátságvidék), szerkezeti morfológia. Sárga: szerkezeti morfológia. Vörös: korallzátonyok, vulkánok, antarktiszi jégmentes területek. Szürke: szárazföldi szintvonalak, summer, selfjég. A metszetek hat színnel nyomottak, ezek: fekete, vörös, narancs, sárga, püspöklila és zöld.

Ugyancsak kandidátusi dolgozatom dokumentálja a munka legfontosabb szereplôit: „A $40 \mathrm{~cm}$ átmérôjú szétszedhető, szerkezeti Föld-modell... Készült a Kartográfiai Vállalat 2. Szerkesztố osztályán, 1986-ban, dr. Hajdu Lajos újításának felhasználásával, a TANÉRT megrendelésére. Irányítószerkesztő: Márton Mátyás. Tervezte: Kovács Balázs (szárazföldi és tengeri tematikus tartalom). Rajz: Agárdi Anna. Litográfia: Agárdi
Anna, Balla Zsuzsa, Márton Mátyás, Nagy Borbála (a $25 \mathrm{~cm}$-es földgömb anyagának felhasználásával).” A rajz itt is a tisztázatirajz-készítést jelenti. Végezetül pedig megjegyzendô, hogy a nyomtatást a vállalat Sokszorosító osztálya, a kasírozást pedig a TANÉRT végezte. Az 1986 végére a KV-nál megszületett magyar földgömbtérkép- és metszetnyomatok felhasználásával készült glóbuszok a kasírozást követôen csak 1987-ben kerülhettek piacra.

\section{Néhány szó az angol változatról}

Mint korábban láttuk, 1986 folyamán elkészült a teljes angol és orosz nyelvú névanyag szakmai és nyelvi lektorálása is, ide értve a földgömbtérkép földrajzi neveit éppúgy, mint a metszetek feliratozását. Ennek ellenére a KV nem kapott a TANÉRT-tôl megbízást a munka folytatására. Pedig csupán a két nyelv mutációs névanyagának elkészítése volt hátra, a teljes színes anyag már rendelkezésre állt, mivel a feldolgozás a színpárhuzamban történố nyomtatás lehetôségének figyelembevételével történt.

Csak 1988-ban érkezett megrendelés a munka folytatására, és az is csupán az angol változat elkészítésére vonatkozott (4. ábra). Ebben az esztendôben - szinte az egész év folyamán - szabadságon voltam. (A kandidátusi dolgozatom elkészítéséhez járó tanulmányi és éves rendes szabadságomat töltöttem.) Fájlaltam, amikor értesültem róla, hogy a munka folytatódik, de megnyugodtam, hogy kiváló irányító térképszerkesztố kolléganôm,

Bardócz Lászlóné12 vezetésével készül az angol mutáció. Ilyen módon a munka részleteirôl nem bírok adatokkal. Nem lebecsülve a munkát, azért elmondható, hogy egy lektorált névanyag korrekt kartográfiai feldolgozása egy olyan nagy gyakorlattal bíró szakembernek, mint amilyen Bardóczné volt, nem jelent különösebb kihívást.

Ez a glóbuszváltozat azonban nagy elismerést hozott a magyar kartográfiának! A Nemzetközi Térképészeti Társulás a következố esztendôben éppen hazánkban, Budapesten a Vigadóban tartotta kétévenként megrendezett konferenciáját, amely a ragyogó augusztusi idóben a több mint 800 résztvevôvel, igen sikeresen zajlott. A konferenciával párhuzamosan a Budavári Palotában nemzetközi térképkiállítás is volt, s az itt bemutatott kartográfiai termékeket kilenc kategóriákban díjazták. A két kategóriagyốztes magyar termék egyike - a szemléltetôeszközök kategóriájában - éppen a Föld-modell angol nyelvú változata volt (AnsonGutsell 1989, Papp-Váry 1990, Rátóti 1990).

\section{A készüló orosz nyelvú virtuális glóbuszról}

Ez év januárjában kézirataimat rendezgetve a Tanszékünkön, készülve a következố földtudományi doktori iskolai félévre, két anyag is kezembe akadt, amelyeket az oktatásban

\footnotetext{
${ }^{12}$ A Szovjetunióban a Moszkvai Geodéziai, Légifényképezési és Kartográfiai Egyetemen 1967-ben kartográfus diplomát szerzett.
}

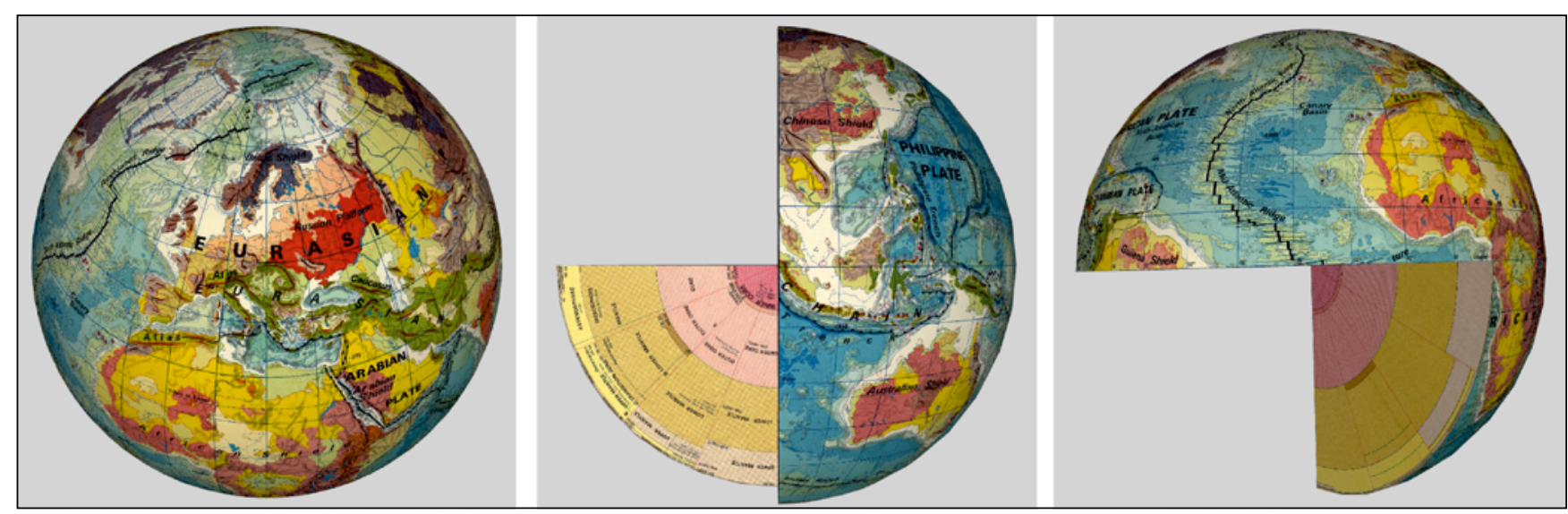

4. ábra. A glóbusz angol nyelvú változatai a VGM-ben. Összerakva: ID 68, az egyik: ID 67 és a másik fele: ID 66 


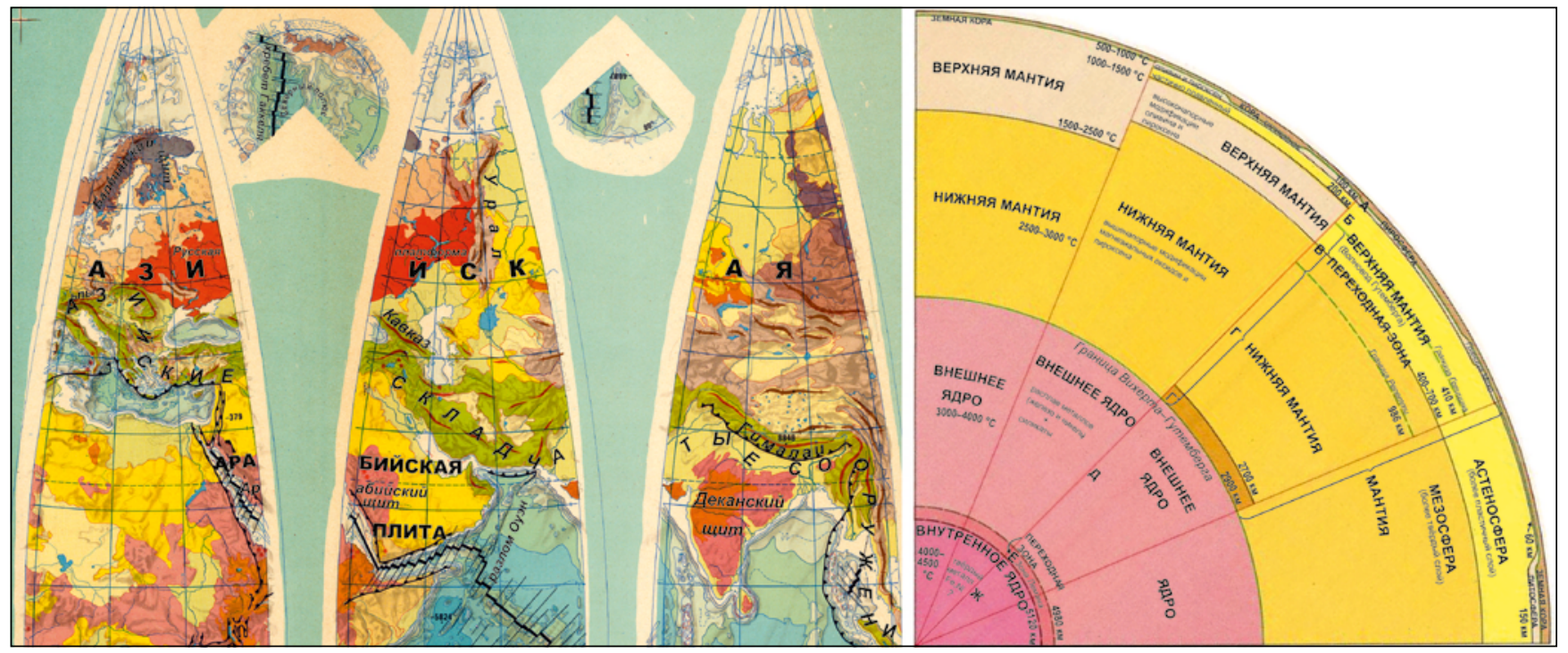

5. ábra. A készülő orosz nyelvü glóbusz gömbszegmens-részei és egy metszete

korábban is használtam. A $25 \mathrm{~cm}$-es domborzati földgömbökhöz készített szerkesztôi utasításom és a 40 cm-es Föld-modell nálam lévô dokumentummásolatai. Ebben a félévben a Térképszerkesztés, -tervezés II. (Földgömbök) tárgy van soron. A I-es (általános) félév után már csak egy hallgatóm, Gerzsenyi Dávid maradt. Majd beütött a koronavírus is. A távoktatás anyagát összeállítottam, és megállapodtunk abban, hogy az átadott anyag alapján szükség szerint tartunk konzultációkat (telefonon, e-mail-ben), illetve hogy a gyakorlati munka keretében elôkészítjük a szétszedhetô Föld-modell magyar és angol példáit követve egy orosz nyelvû virtuális glóbusz anyagát. Így kanyarodott vissza a téma ismét tanszéki hallgatónkhoz.

Mint korábban láttuk, az orosz nyelvú anyag anyanyelvi és szakmai lektorálása még 1986-ban megtörtént, ezzel nem volt gondunk. Csupán olyan nyomataink nem voltak, amelyen nem szerepel magyar vagy angol nyelvú földrajzinév-, illetve metszetnévanyag. Ezeket tehát törölni kellett a szkennelt digitális állományban. Tanári gömbrôl lévén szó a nevek megírása igen markáns, hogy viszonylag messzebbrôl is látható legyen. Ezért a törölt betúhelyeket retusálni kellett: megfelelô színnel pótolni a törölt színfelületeket és rajzi vonalakat (fokhálózat, szintés mélységvonalak stb.) Ezt a feladatot Gerzsenyi Dávid oldotta meg a doktori képzés gyakorlati részeként. A régmúltban szerzett orosz nyelvtudásommal viszonylag könynyen megbirkóztam a kéziratos névanyag számítógépes feldolgozásával. Megállapodtunk abban is, hogy a vizsgaidôszakot követốen kerül sor a szelvények georeferálására és a virtuális Föld-modell elkészítésére a Virtuális Glóbuszok Múzeuma számára. Így olyan egyedülálló orosz nyelvú földgömböt hozunk létre, amelynek névanyagterve több mint 30 esztendốt pihent az íróasztal fiókjában, miközben korábban testet öltött magyar és angol nyelvú testvérei lassan „kihalnak”, és már ôk is csak a Virtuális Glóbuszok Múzeumában találkozhatnak orosz nyelvú „kisöcscsükkel" (5. ábra).

\section{Irodalom}

Anson, Roger W. - Gutsell, Bernard V. 1989 The Award of Prizes. ICA Newsletter, Number 14, October 1989 pp. 7-8.

Kovács Pál - Márton Mátyás 1989. Globes of the Cartographia. In: Csáti E. [Editor]: Hungarian Cartographical Studies. Hungarian National Committee, Internat. Cartogr. Assoc., Budapest; pp. 61-69. http://lazarus.elte.hu/hun/dolgozo/marton/globus/aglobes.htm

Márton Mátyás - Kôvári József 1984a. Az óceán- és tengerfenék-domborzat ábrázolása kis méretarányú térképeken. (Gyakorlat és lehetôségek.) MÉM OFTH pályamú. Kézirat, Budapest, p. 95

Márton Mátyás - Kôvári József 1984b Jelentés a 820013 munkaszámú kutatási feladat (A tengerfenék-domborzat ábrázolásának vizsgálata) végrehajtásáról. Kézirat, Kartográfiai Vállalat, Budapest, p. $1+95$
Márton Mátyás 1985a. Az óceán-és tengerfenék domborzata. Tenger alatti felszínek ábrázolása kis méretarányú térképeken. Doktori értekezés. Kézirat, ELTE, Budapest, p. 129 http://lazarus.elte.hu/hun/dolgozo/marton/ doktori/d-00tart.htm

Márton Mátyás 1985b. Szerkesztối előírás a 25 $\mathrm{cm}$ átmérôjû́ természetföldrajzi földgömb munkarészeinek elkészítéséhez. Kézirat, Kartográfiai Vállalat, Budapest, p. $4+2$ http://lazarus.elte.hu/hun/dolgozo/marton/tevekeny/szerk $25 \mathrm{~g}$.htm

Márton Mátyás 1988. A Kartográfiai Vállalat földgömbjei. Geodézia és Kartográfia 40. évf. 1. szám pp. 42-48.

Márton Mátyás 1991. Tengervízzel fedett felszínek ábrázolása kis méretarányú térképeken. Kandidátusi értekezés. Kézirat, ELTE, Budapest, $151+79$ pp. Térképmelléklet: A Föld szilárd felszíne. http://lazarus.elte. hu/hun/dolgozo/marton/kandidat/ktart. $\underline{\mathrm{htm}}$

Márton Mátyás 2002. Százesztendôs „Az óceánok általános mélységtérképe”. Földrajzi Közlemények, CXXVI. (L.) kötet 1-4. szám, pp. 103-117.

Nagy világatlasz 1985. Kartográfiai Vállalat, Budapest, p. 424

Papp-Váry Árpád 1990. Az ICA 14. konferenciája. Geodézia és Kartográfia, 42. évf. 1. szám, pp. 7-24.

Rátóti Benô 1990. A Budavári Palota nemzetközi térképkiállítása az ICA-konferencia alkalmából. Geodézia és Kartográfia, 42. évf. 1. szám, pp. 65-70.

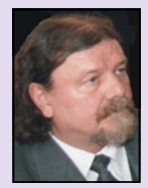

Dr. Márton

Mátyás

professor emeritus

ELTE Térképtudományi és Geoinformatikai Tanszék matyi@map.elte.hu 